\title{
Habitat Edge Contrast as an Indicator to Prioritize Sites for Ecological Restoration at the Landscape Scale
}

\author{
Cristian Echeverria*, Paula Gatica \& Rodrigo Fuentes
}

Laboratorio de Ecología de Paisaje, Facultad de Ciencias Forestales, Universidad de Concepción, Concepción, Chile

\begin{abstract}
Forest restoration at the landscape level has required the development of criteria and methods to prioritize sites of restoration. In this study, we analyzed the spatial patterns of habitat contrast edge to prioritize sites for restoration in a protected area in southern Chile. The edge contrast index (ECON) was estimated and mapped for each pairwise combination of habitat type, based on community composition and structure ecological variables. Correlation length, as a measure of landscape connectivity, was calculated to analyze the effect of restoring high-contrast edge zones on focal habitat continuity. Approximately, $20 \%$ of the landscape area was composed of patches of high-contrast habitat edge (ECON $250 \%$ ). Out of the total edge length, $91 \%$ corresponded to high-contrast edges between the focal habitat and forest plantations of Eucalyptus globulus and Pinus radiata and stands invaded by Acacia spp. Only $9 \%$ corresponded to low-contrast edges $(<0.5)$ with natural forests. The highest ECON corresponded to patches both invaded by alien species (80-90\%) and planted with exotic tree species (60-70\%) that were adjacent to the focal habitat patches. Zones of high contrast that were dissecting the focal habitat patches were prioritized for restoration. The correlation length increased from 1,822 to 2,211 $\mathrm{m}$ for the current and the restoration scenario, respectively. Landscape planning should strive to reduce edges between suitable and unsuitable habitats, taking into account edge sensitivity of forest-dependent species and the spread of invasive species.
\end{abstract}

Key words: Edge Contrast Index, Connectivity, Invasive Species, Fragmentation, Chile.

\section{Introduction}

Although landscape ecology has a relevance to restoring the ecological integrity, landscape spatial patterns in broad-scale habitat restoration remain poorly understood (Knight \& Landres 2002; Newton et al. 2012). Forest restoration at the landscape scale has required the development of methods and criteria to prioritize sites of restoration (Orsi et al. 2011a; Tambosi et al. 2013). However, few efforts have been conducted to prioritize areas of restoration by analyzing the spatial patterns of forest habitat at the landscape scale (Orsi \& Geneletti 2010). Some studies have emphasized that connectivity is a priority attribute of the landscape spatial configuration that has to be recovered in order to improve biodiversity (Luque et al. 2012; Tambosi et al. 2013). This is mainly due to the fact that a reduction in connectivity can lead to a decline in species dispersal, gene flow and even local extinction (Bennett 2003).

The sharpness of habitat edges and contrast across habitat boundaries can directly affect the connectivity, as they can determine the degree of movement of organisms across

\section{*Send correspondence to: Cristian Echeverria}

Laboratorio de Ecología de Paisaje, Facultad

de Ciencias Forestales, Universidad de

Concepción - UdeC, Victoria 631, Concepción, Chile

E-mail: cristian.echeverria@udec.cl the landscape (Peyras et al. 2013; Stevens et al. 2006). A marked contrast in the community attributes at the interface (high-contrast forest edge) between natural habitats and human-related land can inhibit many organisms from readily moving across the edge (Wiens et al. 1985). Applying resistance estimates of high-contrast edges to improve connectivity have been highlighted for the implementation of wildlife corridors and biodiversity conservation (Zeller et al. 2012). However, despite the importance of edge contrast for connectivity, very few studies have applied connectivity metrics that consider edge permeability for restoration prioritization (García-Feced et al. 2011; Orsi et al. 2011b).

In this study, we examined the spatial patterns of habitat forest edge contrast in order to prioritize sites for restoration at the landscape scale. We also analyzed the impact of restoring these sites on changes in landscape connectivity.

\section{Method}

\section{Study area}

A map of habitat type was created using aerial photography and field surveys for the National Reserve Nonguen (hereafter, Nonguen), which is a protected area located 
at $12 \mathrm{~km}$ from Concepción city in south-central Chile (Figure 1). Nonguen is a 3,052 ha area comprised of a mosaic of habitat types, including Nothofagus obliqua (Mirb.) Oerst. natural secondary forest, commercial forest plantations of exotic species such as Eucalyptus globulus Labill. And Pinus radiata D. Don and old-growth forest of N. dombeyi (Mirb.) Oerst. Before the creation of Nonguen in 2009, the native Nothofagus species were severely affected by human-set forest fires, forest logging for firewood and timber and conversion to forest plantations of exotic species. These disturbances favored the invasion of alien species such Acacia dealbata Link (Fabaceae), A. melanoxylon R. Brown and Teline monspessulana (L.) K. Koch, which currently form pure stands in Nonguen (Figure 1).

\section{Estimate of habitat edge contrast}

Quantification of the degree of habitat contrast was conducted based on the Edge Contrast Index (ECON), which was selected after reviewing connectivity-related studies (Coxson \& Stevenson 2007; Watling \& Orrock 2010). This index enables the degree of contrast between a patch and its immediate neighborhood to be measured (McGarigal et al. 2002). The ECON was calculated as follows (Equation 1):
$\mathrm{ECON}=\frac{\sum_{\mathrm{k}=1}^{\mathrm{m}}\left(\mathrm{P}_{\mathrm{ijk}} * \mathrm{ECW}_{\mathrm{ik}}\right)}{\mathrm{P}_{\mathrm{ij}}}$

where: $\mathrm{P}_{\mathrm{ijk}}=$ length $(\mathrm{m})$ of edge of patch ij adjacent to habitat types $\mathrm{k} ; \mathrm{ECW}_{\mathrm{ik}}=$ dissimilarity (edge contrast weight) between habitat types $\mathrm{i}$ and $\mathrm{k} ; \mathrm{p}_{\mathrm{ij}}=$ length $(\mathrm{m})$ of perimeter of patch ij.

The index shows the extent to which movement is facilitated or impeded through different patch types across the landscape. ECON can be computed as a contrast-weighted edge density, were each type of edge is assigned a contrast weight. In the present study, edge contrast weight (ECW) was determined based on the vegetation structure and composition variables (Noss 1990) measured in a $20 \times 25 \mathrm{~m}$ sampling plot for each habitat type (Annex $1^{\star *}$ ). ECON was calculated and mapped using the software FRAGSTAT 3.3 (McGarigal et al. 2002) and a Geographic Information System (GIS). A patch with an $\mathrm{ECON}=0$ is when all of the patch perimeter segments involve patch type adjacencies that have been given a zero-contrast weight in the edge contrast weight (ECW) file. On the other hand, ECON=100 is when the entire patch perimeter is maximum-contrast edge (McGarigal et al. 2002).
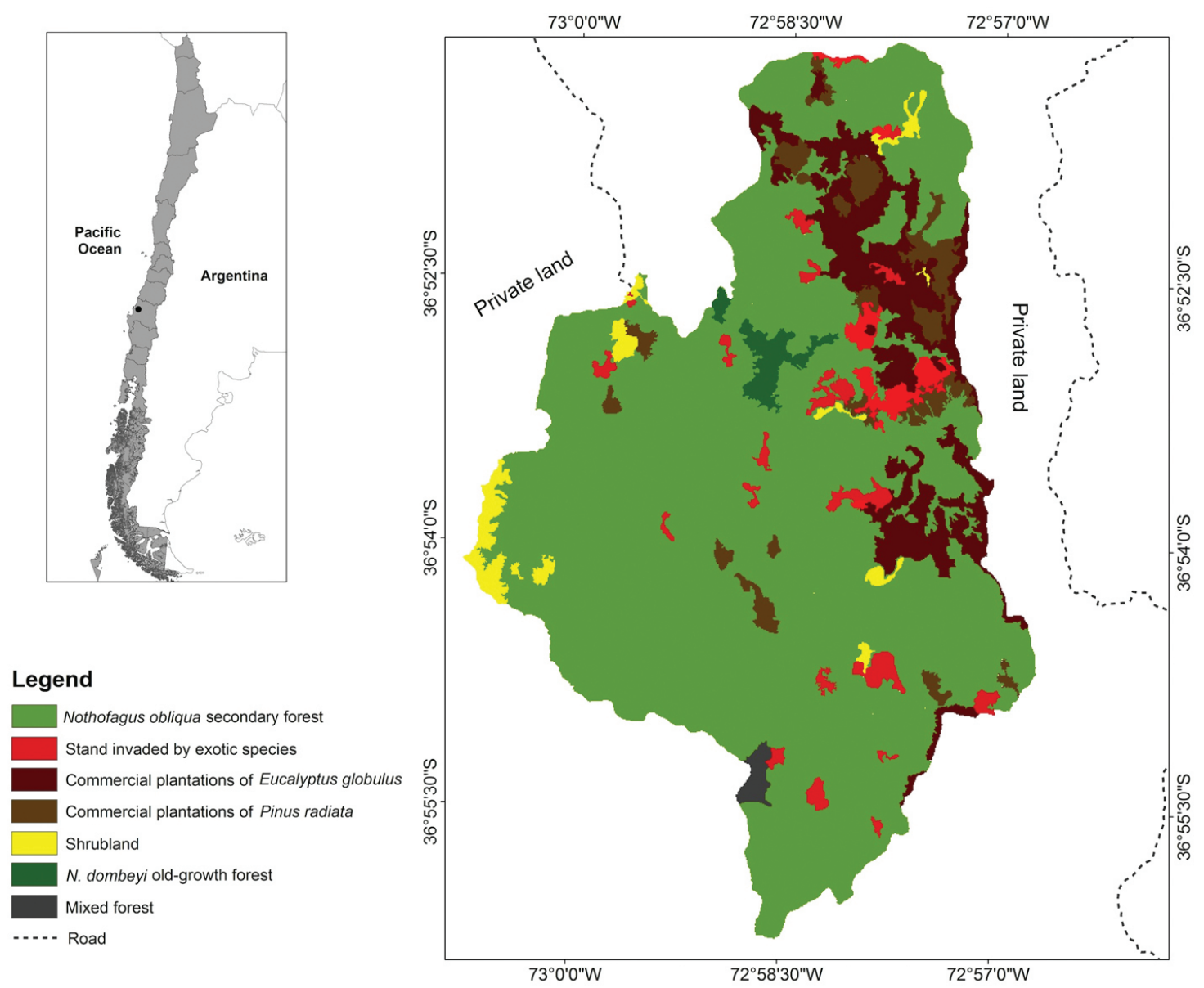

$73^{\circ} 0^{\prime} 0^{\prime \prime} \mathrm{W}$

$72^{\circ} 57^{\prime} \mathrm{O}^{\prime \prime} \mathrm{W}$

Figure 1. Map of habitat types in the study area.

\footnotetext{
${ }^{* *}$ see supplementary material available at abeco.org.br.
} 


\section{Prioritization of restoration sites}

This procedure consisted of four steps. First, from ECON values, we mapped habitat patches in classes of habitat edge contrast. Second, we identified zones of high-contrast forest edges for restoration. Third, a scenario of restoration was simulated in GIS by replacing those zones of high-contrast edge by the focal habitat. Focal habitat type corresponded to the N. obliqua secondary forest, which is the largest natural habitat to be conserved in Nonguen. Here, we digitalized $60 \mathrm{~m}$ wide polygons shaping linear corridors in GIS to assure continuity among focal habitat patches. Corridor width was related to width of edge effects reported for similar habitat types and pixel resolution used in the present study (30 m) (López-Barrera et al. 2007; Murcia 1995). Fourth, landscape connectivity was calculated using the correlation length, which provided the average distance that one can move from a random starting point and travel in a random direction without leaving the focal patch (McGarigal et al. 2002). Changes in the degree of connectivity were analyzed by comparison of values of correlation length between the current map of habitat typesand the restoration scenario.

Patches with an ECON greater than 50 were identified as high-contrast habitat edges. Priority sites for restoration were considered those patches with an ECON greater than 50 (ECON $>50$ means that more than $50 \%$ of the focal habitat edge has high contrast with its neighborhood in terms of composition and structure) as well as those patches that were dissecting focal habitat patches (Figure 1).

\section{Results}

Approximately $20 \%$ of the study landscape was composed of patches of high-contrast habitat edges (Table 1, Figure 2a). The highest values of ECON between forest habitats were reported for stands invaded by $A$. dealbata and $A$. melanoxlyon (ECON=90 and 80, respectively), followed by patches of commercial plantations of $P$. radiata and $E$. globulus (ECON=70 and 60, respectively, Annex 1). The lowest ECON was observed for the interface between the focal patch and natural old-growth $N$. dombeyi forest $(\mathrm{ECON}=30)$. The maximum value of habitat edge contrast was found for the interface with bare ground $(\mathrm{ECON}=1)$, which was represented by the smallest patch in Nonguen (1 ha, Table 1).

For the current scenario, out of the total edge length between the focal habitat and the other habitat types, $91 \%$ corresponded to high-contrast edges $(>50)$ bounded with forest plantations of E. globulus and P. radiata and stands invaded by Acacia spp. (Table 1). These human-related habitats were also characterized by irregular edges and by dividing the largest patch of the focal habitat into two patches (Figure 1). On the other hand, only $9 \%$ corresponded to low-contrast edges $(<50)$ surrounded by old-growth $N$. dombeyi forest and mixed forests (Table 1 ).

Table 1. Values of contrast index and edge length for high and low contrasts between Nothofagus obliqua secondary forest (the largest focal patch in the study) and other habitat types present in the National Reserve Nonguen.

\begin{tabular}{|c|c|c|c|c|c|c|c|}
\hline \multicolumn{4}{|c|}{ Low-contrast edge $(\mathrm{ECON}<50 \%)$} & \multicolumn{4}{|c|}{ High-contrast edge (ECON $>=50 \%)$} \\
\hline $\begin{array}{l}\text { Land use/cover } \\
\text { type }\end{array}$ & $\begin{array}{l}\text { Contrast } \\
\text { index }(\%)\end{array}$ & $\begin{array}{l}\text { Edge } \\
\text { length } \\
(\mathbf{k m})\end{array}$ & $\begin{array}{l}\text { Area } \\
\text { (ha) }\end{array}$ & $\begin{array}{l}\text { Land use/cover } \\
\text { type }\end{array}$ & $\begin{array}{l}\text { Contrast } \\
\text { index }(\%)\end{array}$ & $\begin{array}{l}\text { Edge length } \\
(\mathbf{k m})\end{array}$ & $\begin{array}{c}\text { Area } \\
\text { (ha) }\end{array}$ \\
\hline N. dombeyi old-growth forest & 30 & 9.5 & 37 & $\begin{array}{l}\text { Stands invaded by } \\
\text { Pinus pinaster }\end{array}$ & 50 & 2.6 & 5 \\
\hline \multirow[t]{9}{*}{$\begin{array}{l}\text { Mixed forest } \\
\text { (native and wild exotic trees) }\end{array}$} & 40 & 1.6 & 14 & $\begin{array}{l}\text { Stands invaded by } \\
\text { Pinus radiata }\end{array}$ & 50 & 21 & 63 \\
\hline & & & & $\begin{array}{l}\text { Young Eucalyptus } \\
\text { globulus plantation }\end{array}$ & 60 & 27 & 205 \\
\hline & & & & $\begin{array}{c}\text { Chusquea spp } \\
\text { shrubland }\end{array}$ & 60 & 3.5 & 7 \\
\hline & & & & $\begin{array}{c}\text { Young Pinus radiata } \\
\text { plantation }\end{array}$ & 70 & 23 & 127 \\
\hline & & & & $\begin{array}{c}\text { Shrubland (native } \\
\text { and exotic shrub } \\
\text { species) }\end{array}$ & 80 & 14 & 56 \\
\hline & & & & $\begin{array}{l}\text { Adult Eucalyptus } \\
\text { globulus plantation }\end{array}$ & 60 & 18 & 86 \\
\hline & & & & $\begin{array}{l}\text { Stands invaded by } \\
\text { Acacia melanoxylon }\end{array}$ & 80 & 6.9 & 43 \\
\hline & & & & $\begin{array}{c}\text { Stands invaded by } A . \\
\text { dealbata }\end{array}$ & 90 & 1,3 & 5 \\
\hline & & & & Bare ground & 100 & 0.3 & 1 \\
\hline Total & & 11.1 & 51 & & & 117.6 & 598 \\
\hline
\end{tabular}




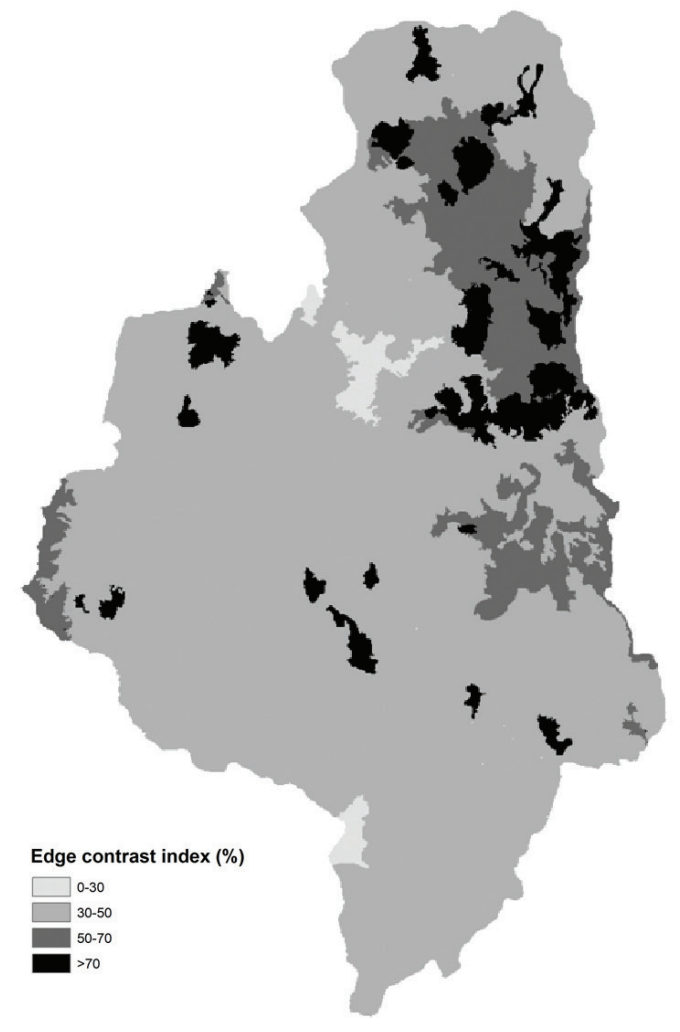

(a)

(b)

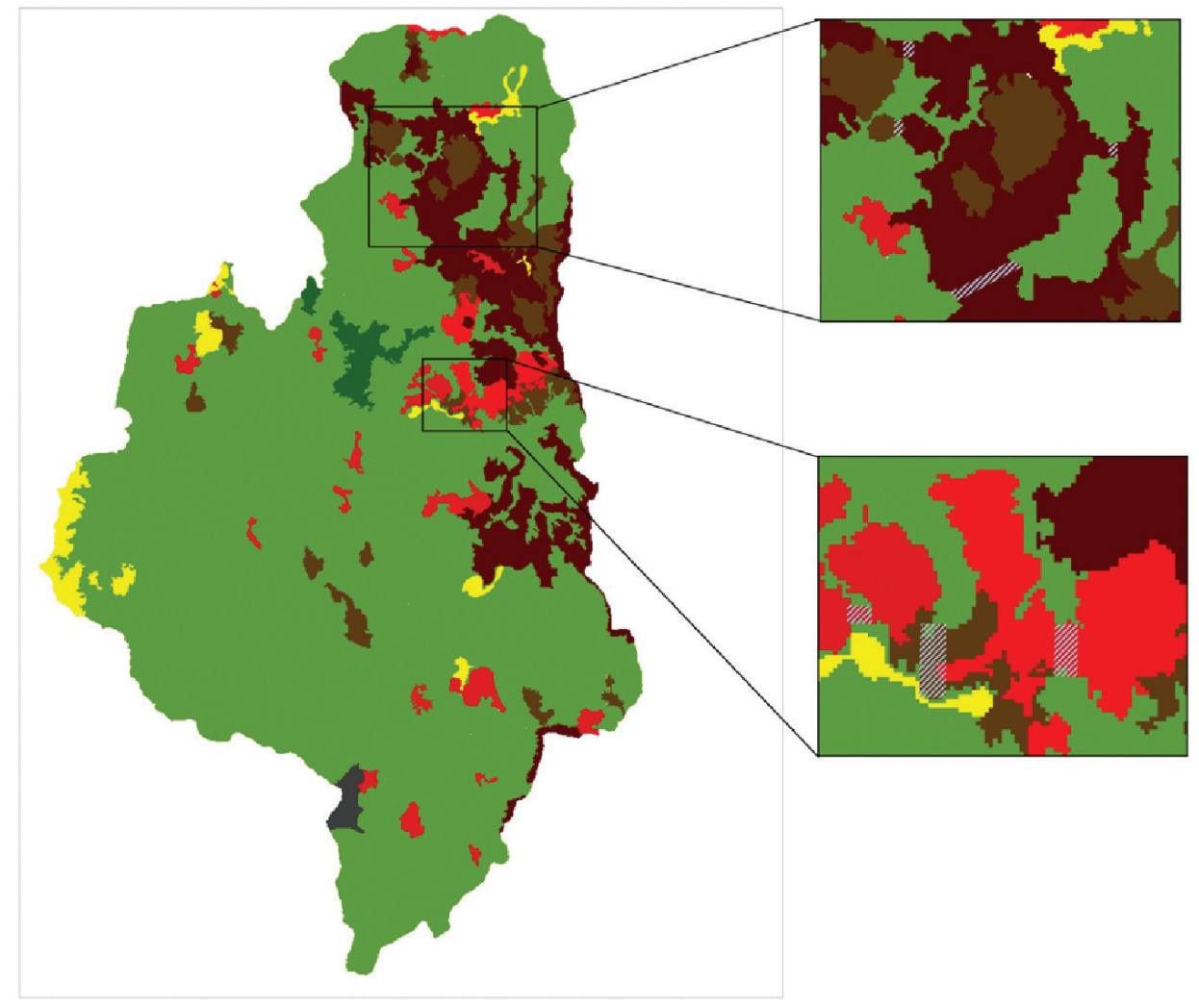

Figure 2. Map of edge contrast index (a) and map of habitat type illustrating location of prioritized sites for restoration (b). Location of these sites corresponded to those patches with an ECON > 50 (a) that were dissecting focal habitat patches (b). 
Priority sites for restoration were defined as edges bounded by Acacia stands and commercial plantations. For the current habitat map, the correlation length was $1,822 \mathrm{~m}$. For the restoration scenario, the restored sites were spatially configured as line corridors connecting focal habitat patches. This caused an increase in the correlation length of $21 \%$, which is equivalent to $2,211 \mathrm{~m}$.

\section{Discussion}

In the present study, the use of ECON enabled zones of high-contrast habitat edges to be identified in a spatially explicit manner. The highest values of ECON corresponded to the interface between natural forest and stands invaded by alien species such as $A$. dealbata and $A$. melanoxylon. These stands were characterized by similar-height trees and an extremely low occurrence of native plant species. These types of habitats have been related to a reduced diversity of native plants in several sites in south-central Chile (Fuentes-Ramírez et al. 2010). In particular, A. dealbata has been reported as a successful invader in diverse environments altered by humans, for example by fires, forest logging and soil disturbances (Lorenzo et al. 2010), creating mono-specific stands in areas where recolonization by native species is extremely difficult (Fuentes-Ramírez et al. 2011). Our results also showed that borders between the focal patch and commercial plantations of E. globulus and P. radiata exhibited high-contrast habitat edges, due to substantial differences in terms of tree height and richness of tree and shrub species. Previous studies have also reported that mono-specific plantations of Eucalyptus may exhibit high-contrast edges with natural habitat due to a more simple composition and structure (Reino et al. 2009).

As reported previously, edge-related metrics can be used to analyze the impact of the landscape spatial pattern on ecological processes and thus to propose general guidelines for management and restoration in fragmented forest landscapes (Zeng \& Wu 2005; Sano et al. 2009). This recommendation can contribute to recovering the ecological integrity, especially in landscapes where the amount, size and spatial configuration of suitable habitats are determinant for edge-sensitive species. In our study, we considered an edge of high-contrast as a proxy of resistance to movement and, therefore, as a spatial indicator of priority sites requiring restoration actions. A limitation of the study is related to the fact that the estimate of contrast weight was based on three ecological attribute variables (one for composition and two for structure). Additional ecological variables related to composition and functioning should be considered in further studies.

Understanding landscape connectivity and its limiting factors is crucial for selecting priority sites for restoration (Orsi \& Geneletti 2010). Contrasting habitat types can directly limit connectivity, as the degree of movement of organisms across the landscape can be reduced (Forman \& Godron 1986; Mesquita et al. 1999). In our study, we demonstrated that the proposed restoration of high-contrast sites dissecting the focal habitat may cause an increase in the extensiveness of the focal habitat; specifically, the restoration of edges bounded by commercial plantations of $P$. radiata and Eucalypts which may have negative effects on species assemblages (Bustamante \& Simonetti 2005; Reino et al. 2009).

Our results revealed an increase in connectivity after simulating the restoration of specific sites of high-contrast habitat. Given these potential consequences on connectivity, landscape planning should strive to reduce and/or soften edges between suitable and unsuitable habitats, taking into account edge sensitivity of forest-dependent species and the spread of invasive species in the study area. Some of those edges can act as barriers or filters for organism movement or provide unsuitable conditions for their occupancy (Lindenmayer et al. 2009).

The new paradigm of biological conservation needs to incorporate the critical roles that landscape spatial patterns play in restoring ecosystem integrity (Knight \& Landres 2002). The present research contributes to the understanding of how the spatial analysis of habitat edge contrast can support the prioritization of sites for restoration and, as a consequence, increase landscape connectivity.

\section{Acknowledgements}

We are grateful to Guillermo Reyes, Juan Iraira, Edison Maldonado and other CONAF representatives for their valuable help in the field. P. Gatica and R. Fuentes are thankful for the CONICYT scholarships.

\section{References}

Bennett AF, 2003. Linkages in the landscape: the role of corridors and connectivity in wildlife conservation. Gland, Switzerland, Cambridge: IUCN. http://dx.doi.org/10.2305/ IUCN.CH.2004.FR.1.en

Bustamante R \& Simonetti J, 2005. Is Pinus radiata invading the native vegetation in central Chile? Demographic responses in a fragmented forest. Biological Invasions, 7:243-249. http://dx.doi.org/10.1007/s10530-004-0740-5

Coxson DS \& Stevenson SK, 2007. Influence of high-contrast and low-contrast forest edges on growth rates of Lobaria pulmonaria in the inland rainforest, British Columbia. Forest Ecology and Management, 253:103-111. http://dx.doi org/10.1016/j.foreco.2007.07.008

Forman RTT \& Godron M, 1986. Landscape Ecology. New York: John Wiley and Sons.

Fuentes-Ramírez A et al., 2011. Survival and growth of Acacia dealbata vs. native trees across an invasion front in south-central Chile. Forest Ecology and Management, 261:1003-1009. http://dx.doi.org/10.1016/j.foreco.2010.12.018

Fuentes-Ramírez A et al., 2010. Relación entre la invasión de Acacia dealbata Link (Fabaceae: Mimosoideae) y la riqueza de especies vegetales en el centro-sur de Chile. 
Gayana Botánica, 67:188-197. http://dx.doi.org/10.4067/ S0717-66432010000200004

García-Feced C, Saura S \& Elena-Rosselló R, 2011. Improving landscape connectivity in forest districts: A two-stage process for prioritizing agricultural patches for reforestation. Forest Ecology and Management, 261:154-161. http://dx.doi. org/10.1016/j.foreco.2010.09.047

Knight RL \& Landres PB, 2002. Central concepts and issues of biological conservation. In: Gutzwiller $\mathrm{K}$ (ed.). Appyling landscape ecology in biological conservation. New York: Springer. p. 22-33. http://dx.doi. org/10.1007/978-1-4613-0059-5_2

Lindenmayer D et al., 2009. Experimental evidence of the effects of a changed matrix on conserving biodiversity within patches of native forest in an industrial plantation landscape. Landscape Ecology, 24:1091-1103. http://dx.doi. org/10.1007/s10980-008-9244-5

López-Barrera F et al., 2007. Fragmentation and edge effects on plant-animal interactions, ecological processes and biodiversity. In: Newton A (ed.). Biodiversity Loss and Conservation in Fragmented Forest Landscapes: The Forest of Montane Mexico and Temperate South America. CABI International. p. 69-101. http://dx.doi. org/10.1079/9781845932619.0069

Lorenzo P, González L \& Reigosa MJ, 2010. The genus Acacia as invader: the characteristic case of Acacia dealbata Link in Europe. Annals of Forest Science, 67:101. http://dx.doi. org/10.1051/forest/2009082

Luque S, Saura S \& Fortin MJ, 2012. Landscape connectivity analysis for conservation: insights from combining new methods with ecological and genetic data. Landscape Ecology, 27:153-157. http://dx.doi.org/10.1007/s10980-011-9700-5

McGarigal K et al., 2002. Fragstats: spatial pattern analysis program for categorical maps. Available from: <www. umass.edu/landeco/research/fragstats/fragstat.html>. Access in: 20 Jan 2010.

Mesquita RCG, Delamonica P \& Laurance WF, 1999. Effect of surrounding vegetation on edge-related tree mortality in Amazonian forest fragments. Biological Conservation, 91:129134. http://dx.doi.org/10.1016/S0006-3207(99)00086-5

Murcia C, 1995. Edge effects in fragmented forests: implications for conservation. Trends in Ecology \& Evolution, 10:58-62. http://dx.doi.org/10.1016/S0169-5347(00)88977-6

Newton A et al., 2012. Forest landscape restoration in the drylands of Latin America. Ecology and Society, 17:21. http://dx.doi.org/10.5751/ES-04572-170121

Noss RF, 1990. Indicators for Monitoring Biodiversity - a Hierarchical Approach. Conservation Biology, 4:355-364. http://dx.doi.org/10.1111/j.1523-1739.1990.tb00309.x
Orsi F, Church RL \& Geneletti D, 2011a. Restoring forest landscapes for biodiversity conservation and rural livelihoods: A spatial optimisation model. Environmental Modelling \& Software, 26:1622-1638. http://dx.doi.org/10.1016/j. envsoft.2011.07.008

Orsi F \& Geneletti D, 2010. Identifying priority areas for Forest Landscape Restoration in Chiapas (Mexico): An operational approach combining ecological and socioeconomic criteria. Landscape and Urban Planning, 94:20-30. http://dx.doi. org/10.1016/j.landurbplan.2009.07.014

Orsi F, Geneletti D \& Newton AC, 2011b. Towards a common set of criteria and indicators to identify forest restoration priorities: An expert panel-based approach. Ecological Indicators, 11:337-347. http://dx.doi.org/10.1016/j. ecolind.2010.06.001

Peyras M et al., 2013. Quantifying edge effects: the role of habitat contrast and species specialization. Journal of Insect Conservation, 17:807-820. http://dx.doi.org/10.1007/ s10841-013-9563-y

Reino L et al., 2009. Distance to edges, edge contrast and landscape fragmentation: Interactions affecting farmland birds around forest plantations. Biological Conservation, 142:824-838. http://dx.doi.org/10.1016/j.biocon.2008.12.011

Sano M et al., 2009. Using landscape metrics and topographic analysis to examine forest management in a mixed forest, Hokkaido, Japan: Guidelines for management interventions and evaluation of cover changes. Forest Ecology and Management, 257:1208-1218. http://dx.doi.org/10.1016/j. foreco.2008.10.005

Stevens VM et al., 2006. Quantifying functional connectivity: experimental assessment of boundary permeability for the natterjack toad (Bufo calamita). Oecologia, 150:161-171. PMid:16896772. http://dx.doi.org/10.1007/ s00442-006-0500-6

Tambosi LR et al., 2013. A Framework to Optimize Biodiversity Restoration Efforts Based on Habitat Amount and Landscape Connectivity. Restoration Ecology. http://dx.doi.org/10.1111/ rec.12049

Watling J \& Orrock J, 2010. Measuring edge contrast using biotic criteria helps defineedge effects on the density of an invasive plant. Landscape Ecology, 25:69-78. http://dx.doi. org/10.1007/s10980-009-9416-y

Wiens J, Crawford CS \& Gosz JR, 1985. Boundary dynamics: as conceptual framework for studying landscape ecosystems. Oikos, 45:421-427. http://dx.doi.org/10.2307/3565577

Zeller K, McGarigal K \& Whiteley A, 2012. Estimating landscape resistance to movement: a review. Landscape Ecology, 27:777-797. http://dx.doi.org/10.1007/s10980-012-9737-0

Zeng H \& Wu XB, 2005. Utilities of edge-based metrics for studying landscape fragmentation. Computers, Environment and Urban Systems, 29:159-178. http://dx.doi.org/10.1016/j. compenvurbsys.2003.09.002 